\title{
Workload, mental health and burnout indicators among female physicians
}

\author{
Zsuzsa Győrffy ${ }^{1 *}$, Diana Dweik ${ }^{2}$ and Edmond Girasek ${ }^{3}$
}

\begin{abstract}
Background: Female doctors in Hungary have worse indicators of physical and mental health compared with other professional women. We aimed to cast light on possible indicators of mental health, workload, and burnout of female physicians.

Methods: Two time-points (T) were compared, in 2003 (T1 $n=408)$ and 2013 (T2 $n=2414$ ), based on two nationally representative surveys of female doctors, and comparison made with data from other professional control groups. Independent samples $t$ test or chi-squared test was used both for the two time-point comparison and the comparison between the index and the control groups. The background factors of sleep disorders and burnout were assessed by binary logistic regression analysis.

Results: No significant differences in the rates of depressive symptoms and suicidal thoughts and attempts were detected between the 2003 and 2013 cohorts, but the prevalence of sleep disorders increased. The workload increased, and there was less job satisfaction in 2013 than in 2003, coupled to more stressful or difficult workrelated situations. The personal accomplishment component of burnout significantly decreased in line with the declining work-related satisfaction. Compared to the professional control groups, the prevalence of depressive symptoms, suicide attempts, and sleep disorders was higher among female physicians at both time-points. The number of workplaces, frequency of work-related stressful situations, and intensive role conflict was associated with sleep disorders and decreased personal accomplishment.

Conclusions: In comparison with the other professional groups, female doctors had worse mental health indicators with regard to depression, suicidal ideas, and sleep disorders both in 2003 and 2013 while within professional strata the changes seemed to be less. Increasing workload had a clear impact on sleep disorders and the personal accomplishment dimension of burnout.
\end{abstract}

Keywords: Female physicians, Mental health, Burnout, Sleep disorders, Workload

\section{Background}

Internationally, there has been a focus on the physical and mental health and on the stress burden that doctors have often to face. The issue is of considerable importance because adverse health will affect the effectiveness of health care [1].

Surveys focusing on the prevalence and severity of different psychological conditions among physicians have indicated that they can be considered as high-risk group concerning mental health. Problems of mental health affect one quarter to one fifth of the general population, but one

\footnotetext{
* Correspondence: gyorffy@chello.hu

${ }^{1}$ Institute of Behavioural Sciences, Semmelweis University, Nagyvárad square

4, Budapest $\mathrm{H}-1089$, Hungary

Full list of author information is available at the end of the article
}

third of doctors have been shown to suffer from at least one such condition $[2,3]$. Tyssen et al.'s longitudinal survey stands out among research on physicians' well-being. Their survey of four time-points found that Norwegian doctors were less satisfied with their lives compared with the members of a professional control group [4].

High levels of stress lead to symptoms of anxiety in almost one third of physicians and depression affects 20 percent of them. Such symptoms are more prominent among female physicians and while the life-time prevalence of depression in the general population is around $25 \%$, it may be up to $39 \%$ among female doctors [5-7]. 
Sleep disorders are prevalent among physicians, especially among females. The prevalence among Spanish female doctors was found to be between 35 and $40 \%$ $[8,9]$. The importance of sleep disorders has been emphasized in many studies which have shown that changing work schedules, night shifts, and the consecutive fragmented sleep could have a severe cognitive and emotional impact on the performance of physicians on the day after a shift. Changing work schedules and sleep deprivation have been suggested as triggers of subsequent sleep disorders [10], and as potential predictors of chronic diseases such as hypertension, diabetes, and cardiovascular disease [11].

There have also been publications that focused on suicidal behavior among physicians. Schernhammer et al. found in a meta-analysis that suicide was almost one and a half times more frequent among male physicians compared with the general population, while in case of female doctors the multiplier was two [12]. Suicidal ideation was also found to be more prevalent among physicians than in the general population $[13,14]$.

Burnout has become a leading challenge within health care in the twenty-first century [15]. Severe emotional and physical strain along with the lack of positive feed-back leads to exhaustion, cynicism, and decreased performance. Dissatisfaction with work is also an important determinant of burnout. Lee et al. in their meta-analysis emphasized that the key dimension of burnout was emotional exhaustion which was found to be a first component in the development of the three dimensions of burnout. Dissatisfaction with distinct aspects of work had the greatest impact on emotional exhaustion. These aspects were autonomy, the power to make decisions, the workload, and working hours [16]. These results were confirmed by Shanefelt et al. among oncologists. They found that not even heavy emotional and physical workload led necessarily to burnout if the physicians were satisfied with their job and the work conditions [17]. Several researchers have mentioned the difficulties of balancing between work and family as important determinants of burnout $[18,19]$. The mental condition of health care staff is, however, not a private issue for those concerned. Burnout can have a significant impact on the prevalence on complications and on malpractice [20,21].

The investigation of female physicians is important. Previous studies have shown that mental vulnerability is more prevalent among female doctors than among their male counterparts. As more women have become medical doctors in recent years, this gains added significance $[9,12]$. In the USA, the proportion of female university students was around $10 \%$ in the 1960s, but has become more than $50 \%$ by now [22]. Interestingly enough, although prognoses from the early 1990s forecasted that every third physicians would be female by 2010, it has become clear that almost half of medical doctors are female and $60 \%$ of medical students. [23-25].

Nevertheless, there is a difference between the Hungarian and the European or North American tendencies. The proportion of female medical students and doctors has been relatively higher in Hungarian health care and in neighboring countries since the 1950s [26, 27]. In contrast with their North American and Western European counterparts, Hungarian female physicians have been working full-time and their workload has been equal to that of their male colleagues for almost seven decades.

This situation has inspired several Hungarian investigations. Győrffy et al. conducted a survey of 408 physicians and the results were compared with the professional control group in the Hungarostudy 2002 database [28]. Symptoms of depression, suicidal ideation, and sleep disorders were more frequent among both male and female physicians compared with other professionals. Reproductive disorders and chronic diseases such as hypertension, cardiovascular, musculoskeletal, gastrointestinal, and gynecological diseases were more frequent among female physicians than in the professional control group. Moreover, certain chronic diseases developed at an earlier age and in clusters. On investigating the background factors of the diseases, contact with harmful chemical agents, increased prevalence of sleep disorders, and a medium to high level of role conflict proved to be important risk factors beyond the traditional ones [29].

In 2013, we performed a nationwide, representative survey with the aim of describing Hungarian physicians' physical and mental health. Our objectives were to compare the results of the two representative surveys of female physicians and to determine the degree and direction of changes with time. According to our hypothesis, this two time-point study supports the notion of the "Central European paradox of female physicians" which refers to that the physical health condition of Hungarian female doctors appears to be worse both in an international and in a Hungarian professional comparison. According to the first analysis of data from 2013, somatic and reproductive health indicators of female physicians suggested that chronic diseases and reproductive disorders were more characteristic of female physicians than in the professional control sample. Trends of the disease indicators were found to be the same as in the earlier survey from 2003 [30].

Our objective in the present analysis was to compare the results of the two representative surveys of female physicians from 2003 and 2013 with special regard to mental health, workload, and work stress. We aimed to determine the degree and direction of changes and to compare the mental health indicators of female physicians with those of a professional control group. 


\section{Methods}

A quantitative, online survey of physicians and dentists working in Hungary was conducted between 9 May and 15 July, 2013. The survey was performed with the permission of the Hungarian Medical Chamber. Ethical permission was obtained from the Ethical Committee of Semmelweis University, Budapest (No: 60/2013).

A link to an anonymous self-administered questionnaire was sent to all potential participants, namely to the registered members of the Hungarian Medical Chamber with valid e-mail address $(n=42.342)$. This was followed by four reminder e-mails. Response rate was $16.18 \%(n=5.607)$. We considered a questionnaire complete in case the participant responded to at least $90 \%$ of the questions. All international studies emphasize that surveys of physicians have lower response rates even in case of traditional, paperbased surveys in comparison with the general population $[31,32]$. The response rates among physicians average about $10 \%$ lower than studies with the general population. Studies on physician surveys have shown that lower response rates were the result of using web surveys alone compared to other survey modes [32].

The data were weighted by gender, age, and type of profession (physicians vs. dentists), according to the data on members of the Hungarian Medical Chamber. After three-dimensional weighting (gender, age, and type of profession), the distribution of data concerning the region and type of workplace were compared with the same type of data from the Hungarian Central Statistical Offices [33]. As a result of the comparison, we found no distributional differences by regions (counties) or by type of workplace (general practice, in-patient and outpatient care). Therefore, we considered our survey material representative. Due to the special nature of their profession, dentists were examined as a separate group. In the present analysis, we limited our attention to female medical doctors $(n=2414)$.

Among mental health indicators, we focused on depressive symptoms, suicidal thoughts and attempts, and different dimensions of sleep disorders. In the analysis, the following work-related variables were used: number of workplaces, working hours per day, changing work schedule (night shifts), satisfaction with work, and frequency of work-related stressful events. In addition, we analyzed indicators of role conflict and burnout.

The first representative study on Hungarian female physicians was conducted in 2003 in which we used random starting point systematic sampling among the registered members of the Hungarian Medical Chamber. Two thirds $(62.7 \%, n=408)$ of the questionnaires completed by the sample chosen were then suitable for statistical analysis. This sample was weighted according to the age and type of workplace dimensions provided by the Hungarian Medical Chamber and the Hungarian
Central Statistical Offices. Thus, our sample was considered representative with regard to age and type of workplace, which are the most important dimensions from the perspective of this survey.

\section{Control group}

With regard to the questions related to mental health (depression, suicidal thoughts and attempts), we used control groups from the population-based surveys Hungarostudy $2002(n=12.640)$ and Hungarostudy $2013(n=2.000)$. The objectives of these representative surveys were to describe the physical and mental health condition of the Hungarian population and to investigate the association between health indicators and certain environmental, social, and economic background factors. Altogether, 12.640 and 2.000 respondents, respectively, were interviewed about their socio-demographic data, health condition, behaviors and habits, and psychological characteristics. Participants of both surveys represented the adult population in Hungary according to gender, age, and place of residence. Each questionnaire consisted of approximately 200 items, and answers were obtained via interviews and self-administered questionnaires. For the comparison with female physicians, the data of 818 and 146 professional women were used, respectively $[34,35]$. Professional women mean women who graduated from college or university. The professional control groups were representative in both time-points; thus, we compared two samples that were adjusted for gender, educational level, and age.

\section{Measurement of mental disorders}

The following tools were used for the assessment of mental health factors:

Sleep disorders were assessed by the shortened Hungarian version of the Athens Insomnia Scale (AIS) $[36,37]$. The original scale consists of 8 items, e.g., such as "Have you had problems with your sleep during the last month that occurred at least three times per week?" or "Do you have difficulties falling asleep?" or "Do you wake up in the middle of the night?" or "Do you wake up too early in the morning?"; total sleep duration (0: no problem, 1: minor problem, 2: considerable problem, 3: serious problem). The cut-off score of 10 in epidemiological surveys is adequate. In our sample, the Cronbach alpha value of the Hungarian version of AIS is 0.874 .

We assessed depression by the shortened version of Beck Depression Inventory (BDI) [38]. Converting the total score of the shortened Beck Depression Inventory to the original BDI, four grades of depression can be distinguished (total score/9 $\times 21$ ): $0-9$ : indicates no depressive symptoms; 10-18: mild depressive symptoms; 19-26: moderate depressive symptoms; above 26: severe depressive symptoms. In our study, the Cronbach alpha value of BDI was 0.86 . 
In the survey, we used the modified question of Paykel's "Suicidal ideation and suicide attempts" questionnaire [39] to assess suicidal thoughts: "Have you ever been preoccupied with suicidal thoughts?" The answers (1. no suicidal thoughts, 2. suicidal thoughts in the past year, 3. suicidal thoughts in the past 5 years, 4 . suicidal thoughts for more than 5 years) were dichotomized as follows: 1 . never have had suicidal thoughts, 2 . have had suicidal thoughts.

To assess suicide attempts, we used the following question: "Have you ever attempted suicide?" Answers (1. never, 2. suicide attempt in the past year, 3. suicide attempt in the past five years, 4 . suicide attempt for more than five years) were dichotomized as follows: 1 . have never attempted suicide, 2 . have attempted suicide.

Burnout was measured using the Hungarian version of Maslach Burnout Inventory-Human Services Survey (MBI) $[40,41]$. This questionnaire of 22 items has three subscales for the measurement of the three different dimensions of burnout: emotional exhaustion subscale (EE), depersonalization subscale (DP), and personal accomplishment subscale (PA). EE consists of nine items and assesses the feelings of being overextended and exhausted in one's workplace (e.g., "I feel depressed at work"). DP has five items and measures an unfeeling and impersonal response toward recipients of one's service, care treatment, or instruction (e.g., "I don't really care what happens to some recipients"). PA consists of eight questions assessing feelings of competence and success in one's work (e.g., "I have accomplished many worthwhile things in this job").

The items were rated on a seven-point Likert scale according to the prevalence of certain work-related feelings (from $0=$ "never" to 6 = "every day"). By the trisection of the total score reached on each subscale, three levels of burnout could be detected (1. mild, 2 . moderate, 3 . severe). Among physicians, severe burnout was characterized by the following cut-off scores: EE $>27$, DP $>10$, and PA $<33$. In the present analysis, Cronbach alpha score of the EE, DP, and PA was $0.909,0.767$, and 0.818 , respectively.

One questions represented a role conflict [42, 43]: "How often do you feel irritated or dissatisfied because of the impression that you cannot balance between your workplace, family, household, or partnership engagements?", which the respondents answered on a fivepoint Likert scale (1. never, 2. rarely, 3. sometimes, 4. often, 5. very often). This variable was dichotomized in certain parts of the analysis: 1 . never, rarely or sometimes experience role conflict, 2 . often or very often experience role conflict.

We aimed to examine the frequency of work-related stressful events by the question: "How often do you experience stressful situations during work?" This was answered by the respondents on a five-point Likert scale (1. not typical at all, 5. absolutely typical). As the result of dichotomization, two categories emerged: 1. not typical at all, 2. typical/absolutely typical.

The degree of subjective workload was assessed by the following question: "How often do you feel overloaded?" which was answered by the respondents on a five-point Likert scale (1. not typical at all, 5. absolutely typical). As the result of dichotomization, two categories emerged: 1 . not typical at all, 2. typical/absolutely typical.

We wanted to detect changing work schedule, with primary focus on shifts by the questions: "Do you work in shifts? How is it scheduled?" The possible answers were dichotomized into two values: 1 . do not work in shifts, 2 . work in shifts. In the second case, we queried the number of hours being on duty.

The number of workplaces was grouped as follows: 1 . only one workplace, 2 . two or more workplaces. In case of weekly working hours, we counted the average daily working hours and dichotomized the results: 1 . less than $8 \mathrm{~h}, 2$. more than $8 \mathrm{~h}$.

\section{Statistical analysis}

During the descriptive analysis, we calculated frequency, mean values, and standard deviation. Deviations of percentages are indicated also. Depending on the type of variables, independent samples $t$ test or chi-squared test was applied. Binary logistic regression analysis was performed to assess the correlation between work-related background factors and the items that became more prevalent among female physicians over a decade (sleep disorders, decreased personal accomplishment). Dependent variables were dichotomized variables of AIS and PA (moderate and severe). Independent variables were age, number of workplaces, amount of working hours, night shifts, work-related satisfaction, work-related stressful situations, and indicators of role conflict.

In the present analysis, we refer to the ratio of valid answers. For the statistical analysis, we used SPSS 15.0.

\section{Results \\ Demographic data of female physicians from the 2003 survey}

The average age of the participants was 45.1 years. Two thirds $(40 \%)$ of female physicians worked in the capital and $25 \%$ in larger and $24 \%$ in smaller cities, whereas $11 \%$ worked in villages.

The majority of the respondents $(71.7 \%)$ were married or cohabiting. With regard to marital status, $8.9 \%$ were single, $4.2 \%$ cohabiting, $67.5 \%$ married, $10.7 \%$ divorced, and $5 \%$ widowed. The $17.8 \%$ of the respondents were childless, whereas $26.7 \%$ of the respondents had one, $46.2 \%$ had two, and $9.3 \%$ had three or more children. Distribution of the participants' workplace was the following: $36.4 \%$ worked in in-patient care, $20.9 \%$ in out-patient care, $26.9 \%$ in general practice, and $15.8 \%$ 
somewhere else (e.g., non-governmental organization, private practice, multinational company, administration).

\section{Demographic data of female physicians from the 2013 survey}

The average age of the participants was 49.5 years. One third $(33 \%)$ of female physicians worked in the capital and $30 \%$ in larger and $30 \%$ in smaller cities, whereas $5 \%$ worked in villages.

With regard to marital status, $10.5 \%$ were single, $13.9 \%$ cohabiting, $59.4 \%$ married, $11.3 \%$ divorced, and $5.4 \%$ widowed. The $23.8 \%$ of the respondents were childless, whereas $21.4 \%$ of the respondents had one, $40.1 \%$ had two, and $14.7 \%$ had three or more children. Distribution of the participants' workplace was the following: $35 \%$ worked in in-patient care, $24.6 \%$ in out-patient care, $26.1 \%$ in general practice, and $14.3 \%$ somewhere else (e.g., non-governmental organization).

\section{The professional control group in $2003(n=818)$}

The control group was adjusted to the sample of female physicians by age; the mean values and the frequencies (\%) are the same in the case of this dimension. Almost one fifth $(11.5 \%)$ of the respondents were single, $70 \%$ were cohabiting and married, $14.1 \%$ were divorced, and 4.4 \% were widowed. Of them, $17.8 \%$ were childless, $26.7 \%$ had one, $46.2 \%$ had two, and $9.3 \%$ had three or more children.

\section{The professional control group in $\mathbf{2 0 1 3}$}

The professional control group (women with a college or university degree) consisted of 146 women. The average age of professional women was 48.1 years. Almost one fifth $(18.1 \%)$ of the respondents were single, $11.1 \%$ were cohabiting, $48 \%$ were married, $18.1 \%$ were divorced, and $4.7 \%$ were widowed. Almost one third (31.9\%) of them were childless, $29.3 \%$ had one, $33.8 \%$ had two, and $4.9 \%$ had three or more children.

\section{Mental health indicators}

Female physicians reported mild, moderate, and severe depressive symptoms more frequently in 2013 than in 2003; however, this was not a statistically significant difference (Table 1). Female physicians were more affected by mild depressive symptoms than the professional control group in both time-points $(p<0.001$ in 2003 and $p<0.002$ in 2013).

\section{Suicidal ideation and suicide attempts}

In 2003, $20.3 \%$ of female physicians reported suicidal thoughts, while in 2013 this ratio was $20.2 \%$. We did not find significant differences from 2003 to 2013.

In comparison with the general population, significantly more female physicians reported suicidal thoughts
Table $1 \mathrm{BDI}$ scores of female physicians and control group in 2003 (T1) and 2013 (T2) \% (n)

\begin{tabular}{lllllll}
\hline BDI & $\begin{array}{l}\text { T1 } \\
(n=406)\end{array}$ & $\begin{array}{l}\text { Control } \\
\text { group } \\
2003\end{array}$ & $p$ & $\begin{array}{l}\text { T2 } \\
(n=3039)\end{array}$ & $\begin{array}{l}\text { Control } \\
\text { group 2013 } \\
(n=128)\end{array}$ & $p$ \\
\hline Mild & 14.2 & 12.3 & 0.283 & 16.8 & 12.8 & $<0.001$ \\
Moderate & 4.1 & 2.5 & 0.004 & 4.6 & 3.8 & 0.789 \\
Severe & 1.2 & 1.2 & 0.348 & 1.2 & 2.1 & 0.412 \\
\hline
\end{tabular}

in 2013 (9.6 vs. $20.3 \%$, respectively; $p<0.001$ ). In 2003, $20.3 \%$ of female physicians reported suicidal thoughts, whereas it was $10.8 \%$ in the control group $(p<0.000$; data not shown). In case of suicide attempts, we did not find differences between the two surveys: the prevalence among female physicians was $2.4 \%$ in 2003, whereas in 2013 it was $2.2 \%$. Suicide attempts were more prevalent in the general population (2.4 vs. $3.5 \%$ in 2013 and 2.4 vs. $2.9 \%$ in 2003), but the difference was not significant.

\section{Sleep disorders}

The quantity of sleep serves as an important indicator of workload. In the comparison of the workday and weekend hours of sleep of female physicians, we did not find significant difference from 2003 to 2013 (Tables 2 and 3). According to Athens Insomnia Scale, $32.5 \%(n=132)$ of female physicians in 2003, while $39.2 \%(n=1162)$ of them in 2013 suffered from any kind of sleep disorder $(p<0.023)$. In 2003, $18 \%$ of the professional control group suffered from sleep disorders, according to AIS scale (no related data from 2013; Tables 2 and 3).

\section{Work-related indicators of female physicians}

The most important work-related characteristics of the female physicians are shown in Table 4. In this analysis, we used data from those female physicians who actively worked at the time when the surveys took place. Significant increases were found with regard to the average number of workplaces from 2003 to 2013: i.e., 1.3 (SD = 0.7160) vs. 2.4 $(\mathrm{SD}=0.984)$, respectively $(p<0.032)$. In $2003,57.8 \%$ of the sample worked more than $8 \mathrm{~h}$ per day on average, whereas this ratio was $82.4 \%$ in $2013(p<0.000)$. In the 2003 sample, $45.4 \%$ of the respondents worked in shifts, while in 2013, it was $48 \%$. We did not find significant difference from 2003 to 2013. Almost one third (30 \%) of female physicians were satisfied or very satisfied with their work in

Table 2 Quantity of sleep on workdays and on weekend days among female physicians in 2003 (T1) and in 2013 (T2) hour (SD)

\begin{tabular}{lll}
\hline Quantity of sleep & T1 & T2 \\
\hline Average hours of sleep & 6.759 & 6.715 \\
on workdays (hours and SD) & $(S D=0.898)$ & $(S D=1.189$ \\
Average hours of sleep on & 8.07 & 7.99 \\
weekend days (hours and SD) & $(S D=1.48)$ & $(S D=1.399)$ \\
\hline
\end{tabular}


Table 3 Distribution of sleep disorders \% (N) among female physicians in 2003 (T1) and in 2013 (T2)

\begin{tabular}{llll}
\hline Sleep disorders & $\mathrm{T} 1$ & $\mathrm{~T} 2$ & $p$ \\
\hline $\begin{array}{l}\text { Sleep disorder that was present at least } \\
\text { three times a week in the past month }\end{array}$ & 32.5 & $39.2(1162)$ & $<0.004$ \\
Problems with sleep induction & 6.8 & $8.1(243)$ & $<0.018$ \\
& $(28)$ & & \\
Interrupted sleep & 19.2 & $14.7(446)$ & $<0.003$ \\
& $(78)$ & & \\
Too early awakening & 6.1 & $10.4(315)$ & $<0.004$ \\
& $(25)$ & & \\
Inadequate duration of sleep & 5.1 & $11(335)$ & $<0.001$ \\
& $(21)$ & & \\
$\begin{array}{l}\text { Inadequate quality of sleep } \\
\text { (independently of quantity) }\end{array}$ & $8(33)$ & $12.4(254)$ & $<0.004$ \\
$\begin{array}{l}\text { Sleep disorder that interferes } \\
\text { with physical and mental } \\
\text { daytime activity }\end{array}$ & 49 & 65.7 & $<0.001$ \\
$\begin{array}{l}\text { Sleep disorder resulting in } \\
\text { exhaustion, fatigue }\end{array}$ & $(200)$ & & \\
\hline
\end{tabular}

2003, whereas the rate of these respondents was $21.3 \%$ in $2013(p<0.000)$. In 2003, $55.3 \%$ of female physicians reported that stressful situations emerged often or very often during work, whereas this number was $65.9 \%$ in 2013 ( $p<$ 0.000 ). In $2003,42.8 \%$ of female physicians reported frequent or very frequent feelings related to role conflict. In 2013, this number was $45.3 \%$. We did not find significant difference from 2003 to 2013.

\section{Burnout}

We examined the changing degree of different dimensions of burnout among female physicians. The average score on the EE was $19.069(\mathrm{SD}=8.72)$ in $\mathrm{T} 1$ and $19.23(\mathrm{SD}=11.99)$ in $\mathrm{T} 2$, on the $\mathrm{DP} 4.3(\mathrm{SD}=5.45)$ in $\mathrm{T} 1$ and $5.6(\mathrm{SD}=5.64)$ in $\mathrm{T} 2$, and on the PA 34.84 $(\mathrm{SD}=9.55)$ in $\mathrm{T} 1$ and in $\mathrm{T} 234.6(\mathrm{SD}=8.947), p<$ $0.000)$. The distribution of mild, moderate, and severe scores reached on each subscale of $\mathrm{MBI}$ is shown in Table 5. There was a remarkable increase in the moderate level of depersonalization, and a significant decrease in the moderate and severe level of personal accomplishment from 2003 (T1) to 2013 (T2).

Table 4 Work-related indicators of female physicians in T1 (2003) and T2 (2013)

\begin{tabular}{llll}
\hline Work-related indicators & T1 (\%) & T2 (\%) & $p$ \\
\hline Number of workplaces (average) & 1.3 & 2.48 & 0.032 \\
Daily working hours (more than 8 h) & 57.8 & 82.4 & 0.001 \\
Shift work & 45.4 & 48 & 0.789 \\
Satisfied or very satisfied with work & 30 & 21.3 & 0.001 \\
Stressful situations & 55.3 & 65.9 & 0.001 \\
Frequent or very frequent role conflict & 42.8 & 45.3 & 0.569 \\
\hline
\end{tabular}

Table 5 Burnout of female physicians in T1 (2003) and in (2013) T2 (\%)

\begin{tabular}{llll}
\hline Dimensions of burnout & Mild (\%) & Moderate (\%) & Severe (\%) \\
\hline Emotional exhaustion & & & \\
T1 & 50 & 30.4 & 19.6 \\
T2 & 48.6 & 30.2 & 21 \\
$p$ & 0.256 & 0.196 & 0.423 \\
Depersonalization & & & \\
T1 & 60.7 & 28.1 & 11.2 \\
T2 & 62.3 & 23.7 & 14 \\
$p$ & 0.569 & $<0.001$ & 0.123 \\
Personal accomplishment & & & \\
T1 & 65.3 & 19.2 & 15.5 \\
T2 & 33.7 & 27.8 & 38.5 \\
$p$ & $<0.001$ & $<0.001$ & $<0.001$ \\
\hline
\end{tabular}

Determinants of sleep disorders and decreased personal accomplishment, according to bi- and multivariate analysis

We examined the role of work-related factors in the background of increased AIS scores and decreased personal accomplishment from 2003 to 2013. We also built up a multivariate model to explain these changes. According to the bivariate analysis, high AIS scores were associated with the number of workplaces, the amount of working hours, night shifts, work-related stressful situations, and the intensity of role conflict. Moderate and severe level of decreased personal accomplishment was associated with the amount of working hours, shift work, work-related stressful situations, and the intensity of role conflict. In the background of both sleep disorders and decreased personal accomplishment, more than one workplace, frequent work-related stressful situations, and intensive role conflict were detected by multivariate analysis (Table 6).

\section{Discussion}

It is a paradigm in health sociology that health status has a strong association with the educational level; therefore, highly educated women are less likely to suffer from somatic diseases [44]. However, our previous and present surveys have shown that significant differences in health status can be found even among groups of highly educated people. According to our results, female physicians had worse subjective and objective health indicators in comparison with the professional control group. These results are equivocal with the findings of domestic research groups. On the other hand, the significant deviation from the international trends is obvious [45, 46]. International studies of somatic health emphasize that doctors are more informed about the methods of prevention and health-preserving techniques; moreover, 
Table 6 Work-related determinants of AIS and moderate to severe decrease of personal accomplishment, according to multivariate analysis

\begin{tabular}{lllll}
\hline Variables & AIS OR and Cl 95\% in multivariate analysis & $p$ & PA OR and Cl 95\% in multivariate analysis & $p$ \\
\hline More than one workplaces & $1.354(1.112-1.648)$ & 0.02 & $1.246(1.094-1.420)$ & 0.03 \\
$>8$ h of work/day & $1.087(0.756-1.558)$ & 0.69 & $1.000(0.669-1.528)$ & 0.96 \\
Night shifts & $0.742(0.523-1.058)$ & 0.74 & $0.965(0.678-1.384)$ & 0.78 \\
Low level of work-related satisfaction & $1.000(0.789-1.593)$ & 0.61 & $1.142(0.781-1.648)$ & 0.74 \\
Frequent work-related stressful situations & $1.276(1.056-1.542)$ & 0.01 & $1.197(1.063-1.348)$ & 0.04 \\
Frequent role conflicts & $1.488(1.242-1.783)$ & 0.01 & $1.748(1.541-1.983)$ & 0.01 \\
\hline
\end{tabular}

they have better chances in the early perception and treatment of certain conditions. On the other hand, the emotional and physical burden that characterizes medical profession can lead to the over-representation of health problems among physicians [47-49]. Nevertheless, we did not find similarly negative trends of somatic health indicators among female physicians working in foreign countries; therefore, we consider this as a rather unique Hungarian phenomenon.

In this study, we surveyed representative samples of Hungarian female physicians to describe their mental health, workload, and burnout indicators in two timepoints. The design of a two time-point survey enabled the detection of the degree and direction of changes occurring with time. According to our results, significant changes were detected between the two time-points of data collection, especially in relation with the amount of workload and work stress. On the one hand, the frequency of depressive symptoms and suicidal thoughts did not change markedly. On the other hand, not only the overall prevalence but also that of each item of sleep disorders increased. Also quantity of workload showed an increase: the amount of daily working hours and number of workplaces rose in comparison with the data of the 2003 survey. In line with this, female doctors reported less overall work-related satisfaction and more burdensome and stressful situations in 2013. The intensity of role conflict slightly enhanced, whereas personal accomplishment dimension of burnout decreased markedly in line with decreasing work-related satisfaction. Biand multivariate models showed that heavy workload (number of workplaces, frequency of work-related stressful situations, intensity of role conflict) was associated with higher AIS scores and moderate to severe decrease of personal accomplishment.

Related studies found the prevalence of depression to be $7-56 \%$ among physicians, which was two times more than that of the general population [50]. Researchers in the HOUPE study showed that the prevalence of suicidal thoughts among Swedish and Italian physicians was around $12 \%$ [51]. Studies focusing on physicians affected by insomnia estimated the rate of this condition to be $35 \%$ [52].
In the survey of Hungarian female physicians in 2003, a wide range of chronic diseases were more prevalent among physicians compared with the professional control group. This phenomenon was described as the "health paradox of female physicians". The finding that the prevalence of depression and suicidal thoughts and attempts did not change over a decade needs to be emphasized. However, depression and EP did not change from T1 to T2, while AIS, PA, and the amount of workload did. This might be explained by the following: emotional exhaustion and depression can be considered as a response to emotional strain, whereas sleep disorders and decreased personal accomplishment are more likely to be due to the increased amount of workload. Therefore, it is likely that it is not work-related emotional strain that increased from T1 to T2 change with time, but increasing workload led to more sleep disorders and decreased personal accomplishment, as it was shown by our survey.

A considerable change in the amount of workload and work-related stress was detected. In the background of the increasing workload, the role of the headcount and distribution of different physician groups can be assumed. Migration, ageing, and retirement of doctors are important contributors to the human resource crisis of the health sector. Similarly to the worldwide known phenomenon, migration of physicians is one of the most urgent challenges of health policies. According to the latest data, altogether 948 Hungarian physicians applied for the official work permit needed for working abroad in 2014 [53]. It was shown by a Hungarian study in 2011, that the most important motivations for working abroad were based on better salary, quality of life, perspectives of Hungarian health care, work conditions, appreciation of the community, and professional perspectives in one's field of specialization [54]. Ageing of the medical community also contributes to the ever expanding workload. At present, the most populous age group of practicing Hungarian physicians is between 55 and 60 years. It can be expected that the retirement of such a large cohort would lead to serious shortage in human resources [55]. Especially the ageing of general practitioners and the unresolved succession have been one of the major problems of Hungarian health care for many years. [56]. 
Underfunding of the health sector is the third important contributor to increased workload. Low salaries given to physicians inevitably lead to having more workplaces simultaneously or to taking on extra night shifts. Thus, increasing workload might lead to a more explicit role conflict and to decreased effectiveness, the latter of which was most apparently present in the personal accomplishment dimension of burnout, according to our results. Previous studies highlighted that lowered personal accomplishment is in correlation with the loss of control over one's work, which is a substantial issue of the functioning of Hungarian health care [57]. Nevertheless, it is important to note that the basic dimensions of burnout are depersonalization and emotional exhaustion, and several studies do not consider the personal accomplishment subscale a part of burnout assessment [58]. Personal accomplishment means feeling of competence and successful achievement in one's work with other people [43]. Still, previous domestic studies found significant decrease in this dimension of burnout; therefore, dealing with this issue is inevitable. Moreover, it is the female population, including female doctors, who are primarily affected by household-related workload. According to our survey from 2013, there was no significant difference in the average weekly working hours between male and female physicians, whereas female doctors spent on average much more hours on housewifery than their male counterparts. In line with this, female doctors reported significantly less leisure time than their male colleagues [59].

Besides the outstanding stress burden [60] imposed on medical professionals, several domestic peculiarities contribute to the paradox of Hungarian female physicians. The mentally and physically burdensome work of Hungarian female doctors is further aggravated by phenomena that have recently characterized the Hungarian labor market: ageing and migration of physicians and the general underfunding of the health care sector. Furthermore, there is a widespread overload of roles. Virtually, there is no division of labor in the partner relationships, which results in a significant extra burden due to the "invisible" workload imposed on women (housewifery, caring for children, and the elderly). Also, there are hardly any part-time job options. It is likely that due to all the abovementioned factors Hungarian female physicians are more vulnerable both somatically and mentally compared with other professional women.

Representative samples of female physicians and the comparison with representative, professional control groups compose the primary strength of this research. Furthermore, we used validated tools when examining mental health factors. Among the weaknesses, a few variables (work-related satisfaction, stressful situations, and role conflict) should be mentioned that were assessed by only one item. We also stress the need for further research aimed at disclosing the background factors of mental health and its association with workload. Further limitation is that the methods of data collection in the 2003 and 2013 quantitative surveys differed (paper-based vs. online, respectively). Furthermore, respondents in the two surveys were not the same people. We also have to mention that the exact distribution of professions in the professional group is unknown. A relatively low response rate is a further limitation; however, multi-dimensional weighting was aimed to get respondent groups that were more representative.

\section{Conclusions}

In this study, the paradox of Hungarian female physicians gained further confirmation. In comparison with the general population, female doctors lagged behind with regard to indicators of mental health (depression, suicidal ideation) both in 2003 and 2013. There was a remarkable increase in the prevalence of sleep disorders and lowered personal accomplishment by 2013. These findings were found to be associated with increasing workload.

\section{Ethical approval}

The study was approved by the Ethics Committee of the Semmelweis University, Budapest (ref. number: $60 / 2013$ ). Our study design included anonymous and voluntary answers to online questionnaires from physicians, but no invasive sampling methods or other similar techniques were applied; thus, there was no need for an informal consent from participants. According to the Ethics Committee of the Semmelweis University's statement, "no informal consent is necessary when conducting researches in the field of social sciences". Our research was conducted in full accordance with the World Medical Association Declaration of Helsinki.

\section{Abbreviations \\ AIS: Athens Insomnia Scale; BDI: Beck Depression Inventory; DP: depersonalization subscale; EE: emotional exhaustion subscale; MBI: Maslach Burnout Inventory; OR: odds ratio; PA: personal accomplishment subscale; SD: standard deviation.}

Competing interests

All authors declare that they have no competing interests.

\section{Authors' contributions}

ZG participated in data analysis and interpretation, wrote the manuscript, read, and approved the final version. DD participated in data interpretation, read, and approved the final version of the manuscript. EG participated in planning and designing of the study and approved the final version of the manuscript.

\section{Acknowledgements}

Hungarostudy 2013 was supported by TÁMOP 5.4.1-12 programmes. The Zsuzsa Győrffy was supported by Hungarian Academy of Sciences Janos Bolyai Research Grant. We thank Szilvia Adam who participated the physician survey in 2003. 


\section{Author details}

'Institute of Behavioural Sciences, Semmelweis University, Nagyvárad square 4, Budapest H-1089, Hungary. ²Department of Obstetrics and Gynecology, University of Szeged, Semmelweis st. 1, Szeged H-6725, Hungary. ${ }^{3}$ Health Services Management Training Centre, Semmelweis University, Kútvölgyi st 2, Budapest $\mathrm{H}-1125$, Hungary.

\section{Received: 27 May 2015 Accepted: 23 March 2016}

\section{Published online: 01 April 2016}

\section{References}

1. Wallace JE, Lemaire JB, Ghali WA. Physician wellness: a missing quality indicator. Lancet. 2009;374(9702):1714-21.

2. Firth-Cozens J. Improving the health of psychiatrist. Adv Psychiatr Treat. 2007;13(3):161-8

3. Tyssen R. Health problems and the use of health services among physicians: a review article with particular emphasis on Norwegian studies. Ind Health. 2007:45(5):599-610.

4. Tyssen R, Hem E, Gude T, Grønvold NT, Ekeberg O, Vaglum P. Lower life satisfaction in physicians compared with a general population sample: a 10 year longitudinal, nationwide study of course and predictors. Soc Psychiatry Psychiatr Epidemiol. 2009:44(1):47-54

5. Túry F, Lajtai L. Profession and personality. Psychological problems of physicians and medical students. [Hivatás és személyiség. Az orvostanhallgatók és orvosok pszichológiai problémái.]. In: Kopp M, Berghammer R, editors. Medical psychology. [Orvosi pszichológia.]. Budapest: Medicina Kiadó; 2005. p. 240-8 [Hungarian].

6. Wada K, Yoshikawa T, Goto T, Hirai A, Matsushima E, Nakashima Y, Nakashima Y, Akaho R, Kido M, Hosaka T. Association of depression and suicidal ideation with unreasonable patient demands and complaints among Japanese physicians: a national cross-sectional survey. Int J Behav Med. 2011;18:384-90.

7. Center C, Davis M, Detre T, Hansbrough W, Hendin H, Laszlo J, Litts DA Mann J, Mansky PA, Michels R, Miles SH, Proujansky R, Reynolds CF 3rd, Silverman MM. Confronting depression and suicidale in physicians: a consensus statement. JAMA. 2003;289(23):3161-6.

8. Rodrigez-Muñoz A, Moreno-Jimenez B, Fernandez-Mendoza JJ, OlavarrietaBernardino S, de la Cruz-Troca JJ, Vela-Bueno A. Insomnia and quality of sleep among primary care physicians: a gender perspective. Rev Neurol. 2008;47(3):119-23.

9. Vela-Bueno A, Moreno-Jiménez B, Rodríguez-Muñoz A, OlavarrietaBernardino S, Fernández-Mendoza J, De la Cruz-Troca JJ, Bixler EO, Vgontzas AN. Insomnia and sleep quality among primary care physicians with low and high burnout levels. J Psychosom Res. 2008;64(4):435-42.

10. Guo Y, Liu Y, Huang X, Rong Y, He M, Wang Y, Yuan J, Wu T, Chen W. The effect of shift work on sleeping quality, hypertension and diabetes in retired workers. PLoS One. 2013;8(8):e71107.

11. Vyas MV, Garg AX, lansavichus AV, Costella J, Donner A, Laugsand LE, Janszky I, Mrkobrada M, Parraga G, Hackam DG. Shift work and vascular events: systematic review and meta-analysis. BMJ. 2012;345:e4800.

12. Schernhammer ES, Colditz GA. Suicidale rates among physicians: a quantitative and gender assessment (meta-analysis). Am J Psychiatr. 2004; 161(12):2295-302

13. Tyssen R, Vaglum P, Gronvold NT, Ekeberg O. Suicidal ideation among medical students and young physicians: a nationwide and prospective study of prevalence and predictors. J Affect Disord. 2001;64:69-79.

14. Bernal M, Haro JM, Bernet S, et al. Risk factors for suicidality in Europe: results from the ESEMED study. J Affect Disord. 2007;101:27-34.

15. Lee YY, Medford AR, Halim AS. Burnout in physicians. J R Coll Physicians Edinb. 2015:45:104-7.

16. Lee RT, Seo B, Hladkyj S, Lovell BL, Schwartzmann L. Correlates of physician burnout across regions and specialties: a meta-analysis. Hum Resour Health. 2013;11:48.

17. Shanafelt TD, Gradishar WJ, Kosty M, Satele D, Chew H, Horn L, Clark B, Hanley AE, Chu Q, Pippen J, Sloan J, Raymond M. Burnout and career satisfaction among US oncologists. J Clin Oncol. 2014;32(7):678-86.

18. Dyrbye LN, Sotile W, Boone S, West CP, Tan L, Satele D, Sloan J, Oreskovich M, Shanafelt T. A survey of U.S. physicians and their partners regarding the impact of work-home conflict. J Gen Intern Med. 2014:29(1):155-61. doi:10. 1007/s11606-013-2581-3. Epub 2013 Sep 17.
19. Roberts DL, Shanafelt TD, Dyrbye LN, West CP. National comparison of burnout and work-life balance among internal medicine hospitalists and outpatient general internists. J Hosp Med. 2014;9(3):176-81. doi:10.1002/jhm. 2146. Epub 2014 Jan 16.

20. Shanafelt TD, Bradley KA, Wipf JE, Back AL. Burnout and self-reported patient care in an internal medicine residency program. Ann Intern Med. 2002;136(5):358-67.

21. Prins JT, van der Heijden FM, Hoekstra-Weebers JE, Bakker AB, van de Wiel $\mathrm{HB}$, Jacobs B, Gazendam-Donofrio SM. Burnout, engagement and resident physicians' self-reported errors. Psychol Health Med. 2009;14(6):654-66.

22. AAMC Data Book. Medical schools and teaching hospitals by the numbers 2009 . Washington, DC: American Association of Medical Colleges; 2009. p. 28-9.

23. Levinson W, Lurie N. When most doctors are women: what lies ahead? Ann Intern Med. 2004;2:471-4.

24. Reichenbach L, Brown H. Gender and academic medicine: impact on the health workforce. BMJ. 2004;329:792-5.

25. British Medical Association. Statistics of medical students in the U.K. London: BMA, Health Policy \& Economic Research Unit; 2002.

26. Riska E. Medical careers and feminist agendas: American, Scandinavian, and Russian women physicians. New York: Aldine de Gruyter; 2001.

27. Yearbook of HealthStatistics. [Egészségügyi Statisztikai Évkönyv]Hungarian Central Statistical Office. Hungarian: [Központi Statisztikai Hivatal]. [Hungarian]: KSH; 2014; p.14.

28. Győrffy Z, Ádám S, Kopp M. Morbidity among Hungarian physicians nationwide representative study. [A magyarországi orvostársadalom egészségi állapota - országos reprezentatív minta alapján]Orvosi Hetilap. 2005;146:1383-91 [Hungarian].

29. Győrffy Z. Licence to health: morbidity and stress predictors among female Hungarian physicians. Budapest: Emberi Jogok Magyar Központja Közalapítvány; 2010 [Hungarian].

30. Győrffy Z, Girasek E. Female physicians health. A longitudinal perspective. [Orvosnők egészsége: Mit mutat a longitudinális perspektíva?] Orvosi Hetilap. 2014;155(25):993-9 [Hungarian]

31. Kellerman SE, Herold J. Physician response to surveys. A review of the literature. Am J Prev Med. 2001;20(1):61-7.

32. Flanigan TS, McFarlaine E, Cook S: Conducting Survey Research among Physicians and other Medical Professionals - A Review of Current Literature https://www.amstat.org/sections/srms/proceedings/y2008/Files/flanigan.pdf. Accessed 14 Dec 2015

33. KSH Statistical Yearbook of Hungary 2011. [Központi Statisztikai Hivatal Egészségügyi Statisztikai Évkönyv 2011]. Budapest: KSH; 2013 [Hungarian].

34. Rózsa S, Réthelyi J, Stauder A, Susánszky É, Mészáros E, Skrabski Á, Kopp M. Methodology of Hungarostudy 2002. [A középkorú magyar népesség egészségi állapota: a Hungarostudy 2002 országos reprezentatív felmérés módszertana és a minta leíró jellemzői.]. Pychiatria Hungarica. 2003;18(2):83-94 [Hungarian].

35. Susánszky É, Székely A. Metodology of Hungarostudy 2013. A Hungarostudy 2013 módszertana. In: Susanszky É, Szanto Z, editors. Hungarian Soul. [Magyar lelkiállapot]. Budapest: Semmelweis; 2013. p. 132-5 [Hungarian].

36. Soldatos CR, Dikeos DG, Paparrigopoulos TJ. The diagnostic validity of the Athens Insomnia Scale. J Psychosom Res. 2003:55:263-7.

37. Novák M, Mucsi I, Shapiro CM. Increased utilization of health services by insomniacs - an epidemiological perspective. J Psychosom Res. 2004;56:527-36.

38. Rózsa S, Szádóczky E, Füredi J. The short version of Beck depression scale in a Hungarian sample. [A Beck Depresszió Kérdőív rövidített változatának jellemzői hazai mintán.]. Psychiatr Hung. 2001;16:384-402 [Hungarian].

39. Paykel ES, Myers JK, Lindenthal JJ, Tanner J. Suicidal feelings in the general population: a prevalence study. Br J Psychiatry. 1974;124:460-9.

40. Maslach C, Jackson SE, Leiter MP. Maslach Burnout Inventory Manual. 3rd ed. Palo Alto, California: Consulting Psychologist Press; 1996.

41. Ádám Sz, Mészáros V. Psychometric properties and health correlates of the Hungarian Version of the Maslach Burnout Inventory - Human Services Survey (MBI-HSS) among physicians. [A humán szolgáltató szektorban dolgozók kiégésének mérésére szolgáló Maslach Kiégés Leltár Magyar változatának pszichometriai jellemzői és egészségügyi korrelátumai orvosok körében.] Mentálhigiéné és Pszichoszomatika 2012;(13)2: 127-145. [Hungarian]

42. Firth L, Mellor DJ, Moore KA, Loquet C. How can managers reduce employee intention to quit? J Manag Psychol. 2004;19(2):170-87.

43. Warde C, Allen W, Gelberg L. Physician role conflict and resulting career changes. Gender and generational differences. J Gen Intern Med. 1996;11(12):729-35. 
44. Huisman M, Kunst AE, Bopp M, et al. Educational inequalities in causespecific mortality in middle-aged and older men and women in eight western European populations. Lancet. 2005;365(9458):493-500.

45. Carpenter L, Swerdlow A, Fear N. Mortality of doctors in different specialties: findings from a cohort of 20,000 NHS hospital consultants. Occup Environ Med. 1997;54:388-95.

46. Töyry S, Rasanen K, Kujala S. Self-reported health, illness, and self-care among Finnish physicians: A national survey. Archives of Family Medicine. 2000;9(10):1079-85.

47. West C, Shanefelt TD, Kolars JC. Quality of life, burnout, educational debt, and medical knowledge among internal medicine residents. JAMA. 2011;306:952-60.

48. Tyssen R, Vaglum P. Mental health problems among young doctors: an updated review of prospective studies. Harv Rev Psychiatry. 2002;10:154-65.

49. Grassi L, Magnani K. Psychiatric morbidity and burnout in the medical profession: an Italian study of general practitioners and hospital physicians. Psychother Psychosom. 2000;13:329-34.

50. Fahrenkopf AM, Sectish TC, Barger LK, Sharek PJ, Lewin D, Chiang WW, Edwards S, Wiedermann BL, Landrigan CP. Rates of medication errors among depressed and burnt out residents: prospective cohort study. BMJ. 2008;336(7642):488-91.

51. Fridner A, Belkić K, Minucci D, Pavan L, Marini M, Pingel B, Putoto G Simonato P, Løvseth LT, Schenck-Gustafsson K. Work environment and recent suicidal thoughts among male university hospital physicians in Sweden and Italy: the health and organization among university hospital physicians in Europe (HOUPE) study. Gend Med. 2011:8(4):269-79.

52. Tsai YC, Liu CH. Factors and symptoms associated with work stress and health-promoting lifestyles among hospital staff: a pilot study in Taiwan. BMC Health Serv Res. 2012;12:199.

53. Health Registration and Training Center 2014. [Egészségügyi Nyilvántartási és Képzési Központ]http://www.enkk.hu/documents/statisztika/2014/hatbiz_ 2014_osszes_db_eves.pdf [Hungarian]

54. Girasek E, Csernus R, Ragány K, Eke E. Migration in the Hungarian health sector. [Migráció az egészségügyben] http://www.matud.iif.hu/2013/03/08. htm [Hungarian]

55. Gaál P, Szigeti S, Csere M, Gaskins M, Panteli D. Hungary: health system review. Health Syst Transit. 2011;13(5):1-266. 116.

56. Győrffy Zs, Girasek E. Hungarian Physician Study 2013. ["Orvoskutatás 2013" vizsgálat első eredményei.] Orvosok Lapja 2013:9(10) pp. 5-7. [Hungarian]

57. Adám S, Torzsa P, Gyorffy Z, Vörös K, Kalabay L. Frequent high-level burnout among general practitioners and residents. Orv Hetil. 2009;150(7):317-23 [Hungarian].

58. Maslach C, Schaufeli W, Leiter MP. Job burnout. Annu Rev Psychol. 2001:52(3):97-422.

59. Györffy Zs. Female and male physicians in Hungary. [Orvosnők és férfiak.] In: The healer's health. [Gyógyitók egészsége.] Oriold; 2015. (in press)[Hungarian].

60. Firth-Cozens J. Doctors, their wellbeing, and their stress. BMJ. 2003;326:670-1.

\section{Submit your next manuscript to BioMed Central and we will help you at every step:}

- We accept pre-submission inquiries

- Our selector tool helps you to find the most relevant journal

- We provide round the clock customer support

- Convenient online submission

- Thorough peer review

- Inclusion in PubMed and all major indexing services

- Maximum visibility for your research

Submit your manuscript at www.biomedcentral.com/submit

) Biomed Central 